\title{
Using Bourdieu's Theory of Practice to Investigate the Experience of Ontario College Graduates Who Are Russian, Ukrainian, and Belarusian, and Seek Career Employment and Permanent Residency in Canada
}

\author{
Oleg Legusov \\ University of Toronto, Canada \\ Email: oleg.legusov@mail.utoronto.ca \\ Address: University of Toronto, Toronto, Canada
}

\section{Introduction}

Governments in the developed countries are striving to attract more international students in the hope that many of them will stay in the country after graduation as skilled immigrants. In Canada, the Province of Ontario has two main types of publicly funded institution of higher education: the university and the college of applied arts and technology (CAAT). Twenty-four CAATs were founded in the late 1960s with a mandate to provide fast, inexpensive, practical education for local communities. It should be noted that these colleges differ from American colleges in that they produce job-ready graduates, rather than preparing students for further education on the university level. CAATs offer a wide range of vocational-certificate, diploma, and applied-degree programs that can provide international students with an expeditious way to immigrate. Small wonder that the number of international students at CAATs is growing rapidly.

For most international graduates in Canada, the path to permanent residency, and eventually citizenship, first involves securing employment. Even though research on the labor-market outcomes of international graduates in Canada is advancing (Chira 2013; Bepple 2014; Morris-Lange and Brands 2015), it tends to emphasize university graduates. As a result, the numerous barriers faced by international CAAT graduates who seek jobs on their host country's labor market, such as prejudice and discrimination based on ethnicity, gender, age, and immigration status, are still not well understood. This thesis helps address this knowledge gap by focusing on international CAAT graduates who enter the labor market, and make a new life, in Canada.

\section{The Study}

The thesis investigates the experiences of international CAAT graduates from three former Soviet republics Russia, Ukraine, and Belarus - as they seek career employment and permanent residency in Canada. More specifically, it explores how such graduates acquire and use cultural and social capital to obtain employment commensurate with their credentials and to gain an understanding of Canada's workplace culture.

\section{Methodology}

Qualitative sampling was used to select the participants, with the two main criteria being their gender and type of college credential. The participants were recruited from four of the five Greater Toronto Area (GTA) colleges. According to the Ontario Ministry of Training, Colleges and Universities, $72 \%$ of the international students in Ontario's college system in 2012 attended the five CAATs in the GTA (Popovic 2013). 


\section{Bourdieu's Theory of Practice as a Theoretical Framework}

Pierre Bourdieu's (1977) theory of practice provides the theoretical framework for an analysis of the labor-market integration of 14 women and 16 men. The study examines the relationship between structure and agency, as well as the interplay of three elements of Bourdieu's theory: field, capital, and habitus (Bourdieu 1993). In Bourdieu's formulation, the job market is a field that job seekers try to enter and establish themselves on (Bourdieu 1966). To do so, they need to use, and enhance, their cultural and social capital. For international students, they enter a complex game whose rules they may not be familiar with, because they are newcomers to Canada. The main focus of the research is to determine the extent to which international college graduates succeed in using the social and cultural capital they acquired at home and in Canada to learn the rules of the game. The concepts of career habitus, career field, and career capital, as developed by Iellatchitch et al. (2003), are used to adapt Bourdieu's theory to the research context.

\section{Preliminary Findings}

The preliminary findings, which are based on data collected from in-depth interviews and document analysis, reveal that the participants belong to three distinct age groups: "Teenagers", or those who arrived in Canada shortly after graduating from high school; "Young Adults", or those who were in their 20s and had further life experience when they arrived; and "Mature Adults", or those who were over the age of 30 when they arrived, having left behind established lives.

\section{Implications for Job Market Outcomes}

Differing significantly in terms of career habitus and career capital, the members of the three age groups are likely to have different labor-market outcomes.

Teenagers Group. The members of this group typically have highly educated parents who are successful business owners. In Bourdieusian terms, many of them have inherited the "right" type of career habitus. Furthermore, they possess cultural capital as a result of opportunities their parents gave them: they are well traveled, they attended elite schools, and they started learning English at an early age. Thus they are well equipped to succeed on the career field in their new country.

Young Adults Group. The participants in this group could not leave their countries after high school for reasons such as financial constraints or compulsory military service. After high school, they remained in their home countries, spending three or four years engaged in various activities that had a strong influence on the formation of their career habitus and career capital. As a result, the members of this group are likely to face moderate challenges in the Canadian labor market.

Mature Adults Group. The salient feature of this group is that, even though some of them were still young when the Soviet Union collapsed, socialism had a profound impact on the formation of their habitus in general and their career habitus in particular. Furthermore, their answers to the interview questions suggest that they are the group least inclined to embrace a neoliberal mindset. Thus, of the three groups, this one is likely to have the most difficulty adjusting to the Canadian labor market.

\section{Contribution to Comparative and International Higher Education}


This research is pertinent from theoretical and practical points of view. Given that the tendency of international CAAT graduates to seek employment and permanent residency in Canada is swiftly becoming a key component of governmental strategy to increase skilled-labor immigration, it is vital to understand how well the members of this population are able to achieve their aspirations. The comparative aspect of the study consists of an examination of the labor-market outcomes of international college graduates who come from the same part of the world, but belong to three decidedly distinct generations.

\section{References}

Bepple, Nancy. 2014. "International Students Strategies to Obtain Career-Related Work in Canada after Graduation." Open Collections. University of British Columbia. https://open.library.ubc.ca/handle/2429/51566.

Bourdieu, Pierre. 1966. "Champ Intellectuel Et Projet Créateur." Les Temps Modernes 246: 865-906.

Bourdieu, Pierre. 1977. Outline of a Theory of Practice. New York: Cambridge University Press.

Bourdieu, Pierre, and Richard Nice. 1993. Sociology in Question. London: Sage.

Chira, Sinziana, Pauline Gardiner Barber, \& Chedly Belkhodja. 2013. "[PDF] Dreaming Big, Coming Up Short: The Challenging Realities of International Students and Graduates in Atlantic Canada - Semantic Scholar." https://www.semanticscholar.org/paper/Dreaming-Big,-Coming-Up-Short:-The-challenging-of-ChiraBarber/5314c69a8cf709df 33e84102cdfcb75ccdcb8e22.

Iellatchitch, Alexander, Wolfgang Mayrhofer, and Michael Meyer. 2003. "Career Fields: A Small Step towards a Grand Career Theory?" The International Journal of Human Resource Management 14 (5): 728-50. https://doi.org/10.1080/0958519032000080776.

Morris-Lange, Simon, \& Brands, Florinda. 2015. "Train and Retain. Career Support for International Students in Canada, Germany, the Netherlands and Sweden." https://www.svr-migration.de/en/publications/train-and-retain/.

Oreopoulos, Philip. 2011. "Why Do Skilled Immigrants Struggle in the Labor Market? A Field Experiment with Thirteen Thousand Resumes." American Economic Journal: Economic Policy 3(4): 148-71. https://doi.org/10.1257/pol.3.4.148.

Popovic, Tamara. 2013. “International Education in Ontario's Colleges.” Policy Paper. Toronto, Canada: College Student Alliance. 